\title{
Preparation of tourism development scenarios in Qhaen city in 1404
}

\author{
Mohammad Rahim Rahnama ${ }^{1}$, Marzieh Amini*2 \\ Faculty Member, Department of Geography and Urban Planning Faculty of Literature and Humanities, \\ University of Ferdowsi Mashhad, Mashhad, Iran. \\ Emsil :Rahnamarahim@gmail.com \\ *Ph.D. student, Department of Geography and Urban Planning Faculty of Literature and Humanities, \\ University of Ferdowsi Mashhad, Mashhad, Iran. \\ Email: amini7380@gmail.com
}

\begin{abstract}
Tourism as an effective tool to continue the process of political, cultural and economic development of countries is of particular interest. This research is about identifying the main factors and drawing the believable future in tourism in Qayen. The statistical population of this research includes 15 experts in the field of urban tourism and planning. The data collection method was selected based on the Schwartz pattern and STEEP method (5 main criteria including economic, social, political, social, and technology). The data analysis tool is MIC MAC software were selected. The results show that most of the relationships between the variables are estimated to have 3 or very strong effects Therefore, five factors of the tendency of the province economy to diversify its tourism species, the share of private sectors of the tourism economy, government ownership, specialized human resources, the existence of tourism offices, and construction and reinforcement of tourism infrastructure) were selected as the key factors that have the greatest impact on desirable scenario in the path to tourism in Qayen On the horizon of 1404
\end{abstract}

Keywords: Tourism scenario, crossover impact analysis, Mick Mack, Qayen city

\section{Introduction}

Throughout history, human beings have always been enthusiastic about discovering the future and decoding it based on the inner action. The questions such as "is the future changeable?", "is the future continuation of the present and the past?", and "what will happen in the future?" were the challenges of managers' programing heretofore. They have used different approaches to dealing with future issues, often based on analyzing past processes and continuing them in the future. But in the beginning of the third millennium the foresight science transformed non-coherent and diffused researches in the area of planning to scientifically sound, with rigorous principles and precise methods. Using these methods helps to analyze the processes of the past and discover, devise, and evaluate the possible, probable and desirable future or change it if necessary (Zali et al. 2012).Foresight is widely used today. Therefore, decision makers in the field of geography and urban and regional planning in a world full of transformation require the development of new approaches for prediction and readiness for the future. Meanwhile, one of these important issues which plays a very important role in the economic development of cities and villages and may cause economic growth improvement and increase individuals' life quality by foresight and designing of scenario, is development of the tourism industry (Khatai, and Mousavi, 2008). In fact, tourism is becoming one of the main pillars of the world's commercial economy and many planners mention it as to be the main pillar of development. Tourism is one of the important activities that have enjoyed a special status in the economic development of some countries in recent decades (MirKatouli et al. 2011). As economists call it invisible exports (Taghdisi et al. 2015). In fact, tourism in today's world is considered as an industry that needs special equipment and requires research and development to grow like all other industries (Kazemi 2010). In fact, tourism in many countries of the world is one of the most complex activities of human beings and as a multifaceted activity has many positive effects and functions including job creation, money making, currency attracting and strengthening the infrastructure, and so on (Ghaderi et al. 2011). Hence, Qayen is one of the cities with diverse potential and climate conditions for attracting domestic and foreign tourists, but this city still has not been able to lead to the growth of the tourism industry as well as a source of income generation for individuals. The existence of tourist attractions in the historical, cultural, and natural areas of Qayen city can provide the areas of economic growth of economic, environmental, and social parts and urban well-being in the city and it can be proposed as an important tourist attraction in South Khorasan province and at macro and national levels. However, the existing statistics reflects the weakness of the social and urban economy of the city. Therefore, the present research attempts to identify the key factors and main drivers involved in the development of tourism in Qayen, and then its main elements and factors. By designing possible scenarios in the future, a flexible planning policy and planning framework proportional to the conditions of the region and growth and development of the tourism industry in Cayen is offered. 


\section{Statement of the problem}

Tourism is the Persian equivalent of the word tourism in the English, French and German languages which has been translated into Persian as "Jahaanghardi". It is more about going around and visiting the world, and it does not include domestic travel. Instead, it is used in Arabic as a traveler and refers to people who travel with a specific purpose, such as Naser Khosrow and Sadi. And this term was used in the Persian language until the middle of the 20th century in the above sense, until the term "tourism" replaced it. Today, the tourism industry has flourished in the world where many developing countries with low income sources have been able to promote many of their socio-economic indicators to a great extent, and find solutions for problems such as unemployment, low per capita income, lack of revenues, and cultural issues such as negative attitudes towards these areas, etc. and overcome them. Tourism is a legacy that is usually based on the living and established elements of culture and uses a tangible and intangible past as a source of tourism that includes things such as existing cultures and folk practices of today's life and other immaterial elements.Qayen has a great tourist attraction area of Bozorgmehr, Qalee-kouh, Khunik Cave and many more, but evidences show the lack of the tourism industry development. In particular, existing programs have not succeeded in attracting tourists interested in nature. On the one hand, the flow of tourism in the world has been widely developed. Many countries have been able to improve their status in this sector, and covered many of their problems associated with unemployment, lower per capita income levels, and lower foreign exchange earnings. Because of the significant effects that tourism activities have on the economy of the tourist destinations, much attention is paid to this area of activity. Meanwhile, the most important places that are visited place to the tourists' residence are the most attractive spaces from the past. Nowadays, city planners and city managers are paying attention to the reconstruction of historic districts and cultural centers in addition to establishing residential and shopping centers. It is necessary to mention this point that with more tourists in urban environment, the urban Under-funding problem will be solved to a large extent, and urban managers can better serve their legitimate duties against people. One of the main reasons that caused Qayen to have a positive and historic image is that this city is located in the way of international transit as well as the proximity to Afghanistan which adds to the city's service and tourism role. The environmental and tourism potential of Qayen is also a great opportunity for both domestic and foreign tourists due to the presence of many historical and natural attractions. Therefore, attention to the field of tourism in all micro-macro-levels of planning is of great importance. Considering the climatic capabilities of this city and the fact that there has been no research on the strategy analysis of the tourism sector in Qayen yet, it seems necessary to be done. Hence, to reduce the negative effects of tourism in the city and benefit from it, a strategy should be develop.

\section{Study area}

Qayen, a city in southern Khorasan province, includes three central, Sedeh, and Nimbolook districts. This city is limited by Khaf and Gonabad cities of Khorasan-e-Razawi province in the north, Sarayan in the west, Birjand in the south, and Zirkouh in the east ( Figure 1 ). The center of this county is Qayen, the name of a plain that city is located in. This city is located on the highway of Asia, Mashhad to Zahedan (north-south east of the country), the location of the county and city of Qayen is showed in Figure 1. Also the location of the historical and tourist sites of the city of Qaen are sharply Figures 2 and 3

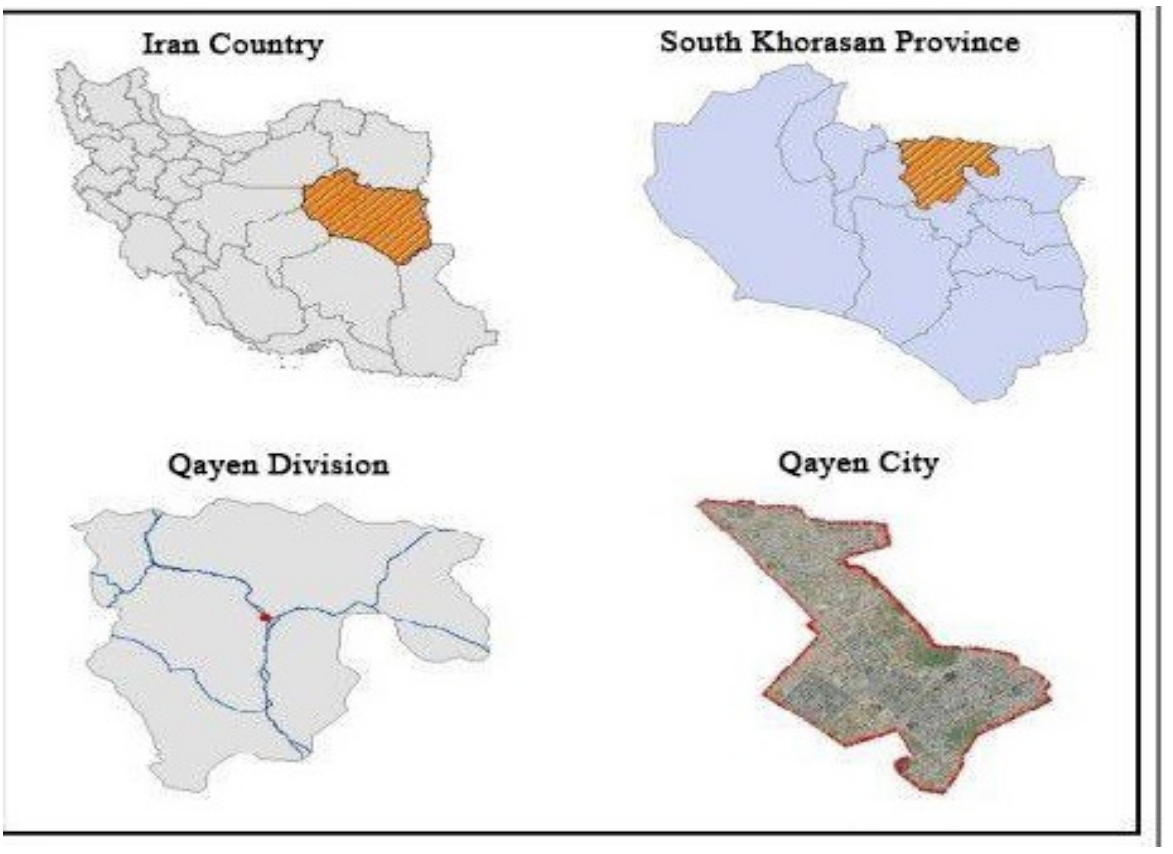

Figure 1. The location of Qayen. 


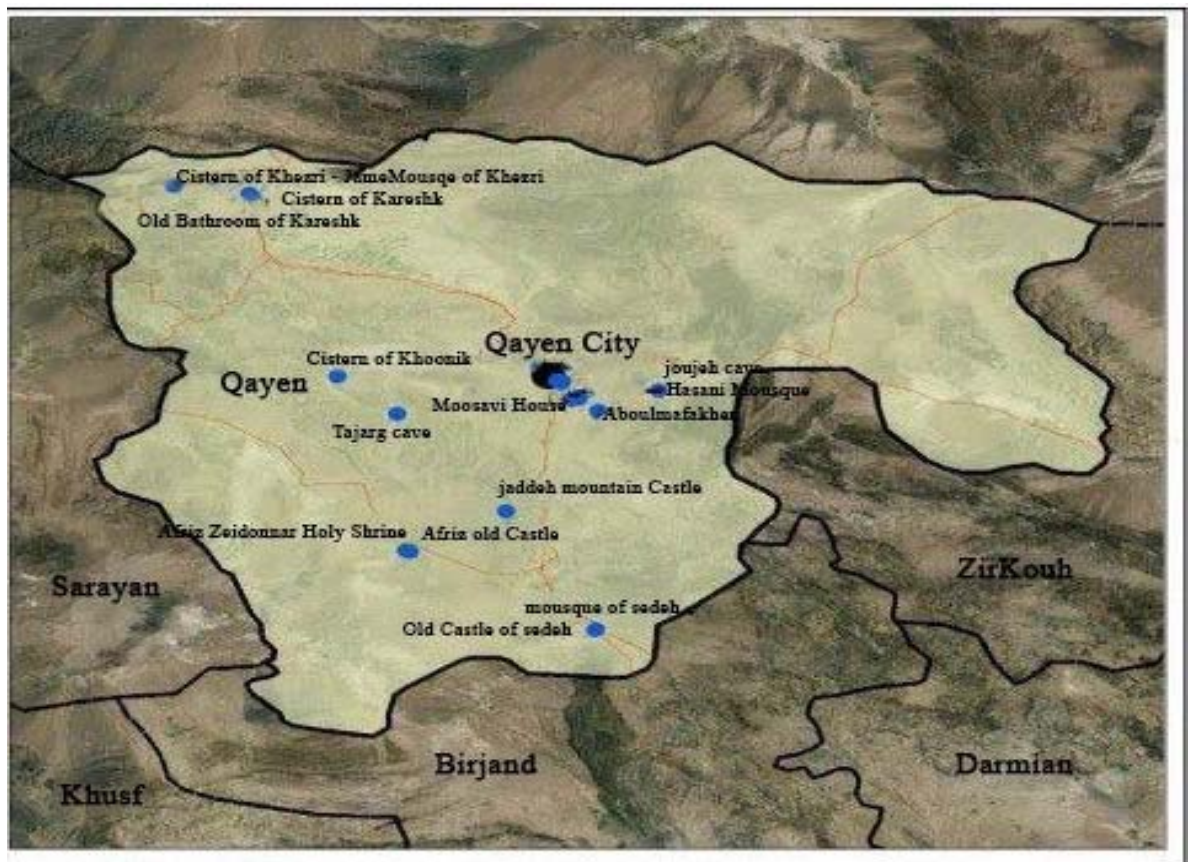

Figure 2. The location of the historical attractions of Qayen.

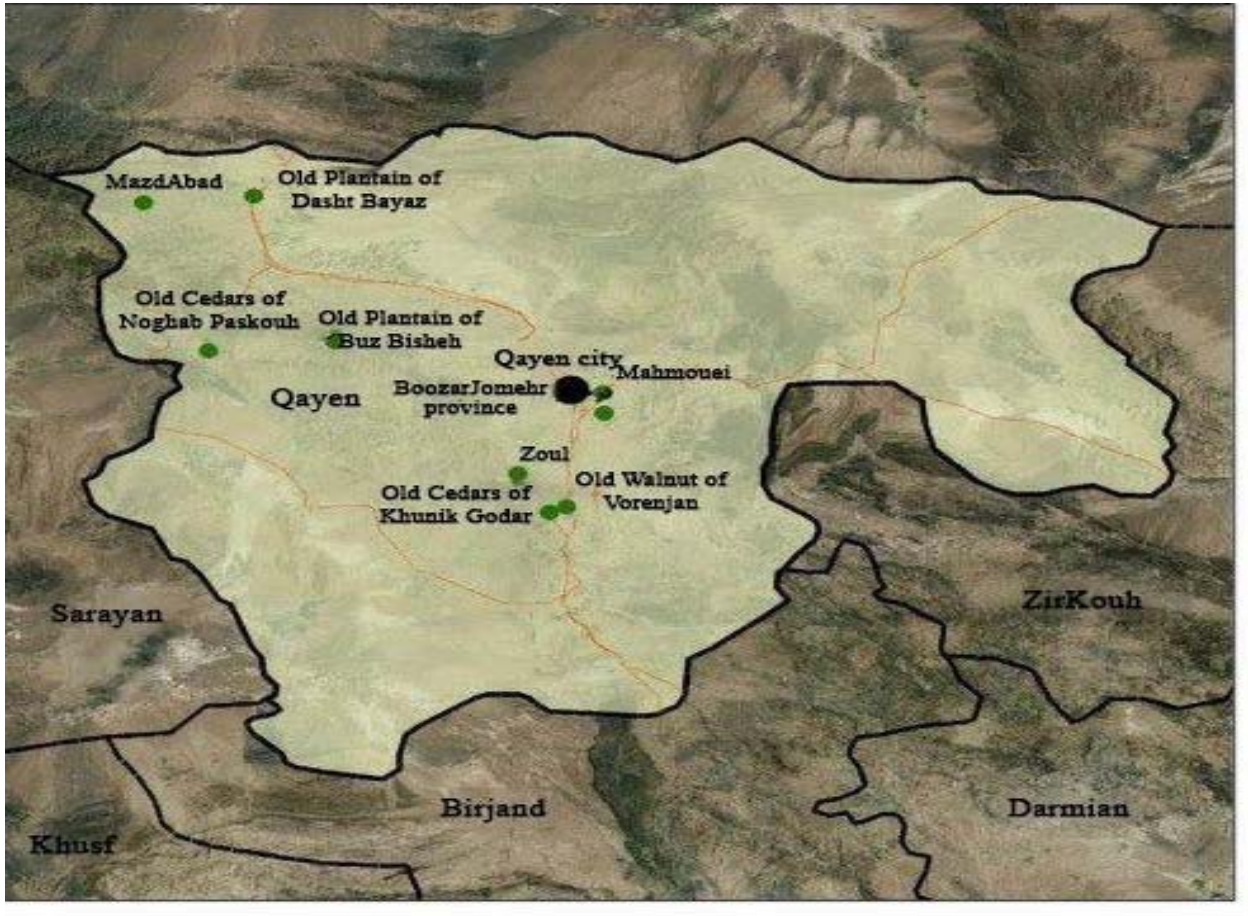

Figure 3. The location of natural attractions of Qayen.

Resource: writers

Qayen is located between 19 degrees, 12 minutes to 19 degrees, 14 minutes east longitude and 33 degrees, 42 minutes to 33 degrees, 41 minutes north latitude. According to the Population and Housing Census, in 2012 its population was 43,323 .

\section{Methodology}

In the present study, Delphi model and MIC MAC software and Schwarz pattern have been used to provide strategic management approaches and foresight studies. MickCam software is designed to perform heavy calculations of the interaction effects matrix. This software first identifies the variables and components in the domain and then introduces it in a matrix like the effect analysis matrix and the degree of correlation between these variables is determined by the experts in the domain and the variables in the rows affect (Zali et al. 2002). Thus, the sum of the variables in the row data, the impact rate, and the sum of the data of the column variables, 
will indicate the degree of impact. The extent of relationships of numeric is measured between 0 and 3 , the numeric are measured as follow: "zero as impacted", "number 1 as a weak effect", "number 2 intermediate effects," and eventually "number 3 as a great effect". Therefore, if $\mathrm{x}$ is the number of known variables, then a $\mathrm{x} x \mathrm{x}$ matrix is obtained.

\section{Delphi method}

The Delphi method was invented in the 1960s, and its name was derived from the Delphi Temple where priests used to predict the future. The main objective of Delphi survey was to obtain a quantitative assessment of the future by allowing experts to comment on different views. This method is most often used in technological forecasting (Rahnema and Maroufi 2015).

The Delphi method can only be considered as a type of structured techniques for conducting an intellectual storm. This method involves the questioning of experts by consecutive replication of a questionnaire. Each repetition includes a "period", and a tool to express the views of experts. The results of each period of survey are collected and comments are analyzed in quantitative and qualitative ways, and audiences in this emerging consensus must explain the reasons for their opposition to consensus. The required number of periods depends on the consensus that scrutiny and research are seeking to achieve. The basic assumption of the conventional Delphi method is that the consensus among the group of respondents is more useful and inspiring than personal beliefs. The main advantage of this method is to do a network work by experts (Khazaei 2010).

The process of Delphi method is shown in the following diagram ( Figure 4 ).

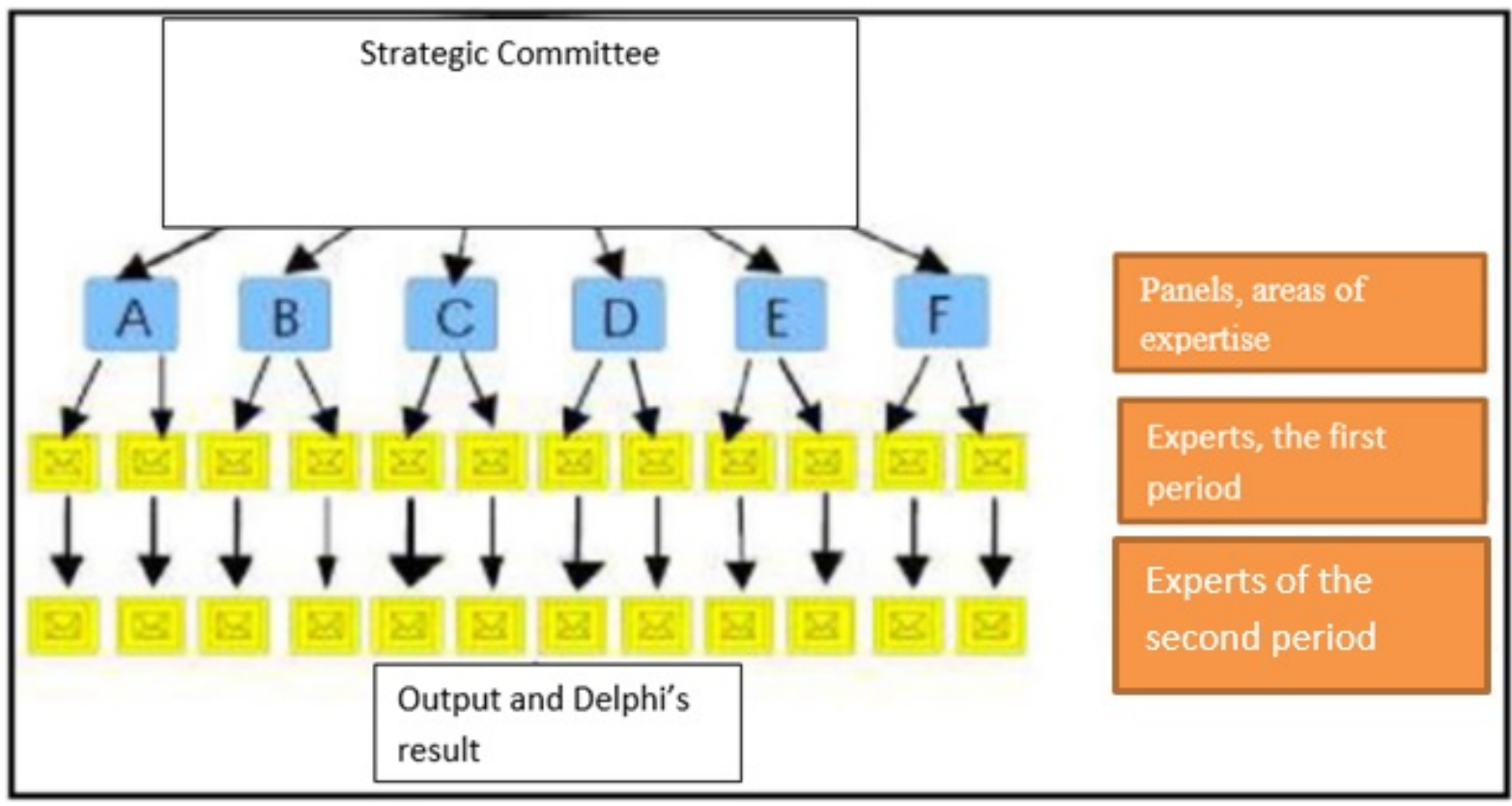

Figure 4. The process of Delphi Studies (Zali, 2002)

\section{Research findings}

The final selection of the main factors affecting the development of tourism in Qayen

Cities are always shaped and developed by effect of various forces and factors, and they are the basis of social and economic phenomena. Cities are transformed by social changes, demographic transitions, economic changes, and technological innovations. As the population grows, activities and investments are also expanding and the body structure changes (Khazaei 2010). If identifying a topic or decision is the first step in planning a scenario, a second step is to provide a list of key factors that affect the considered topic There are various frameworks for identifying the main forces. A common practice is the Plan S1-2T-E3E4-P5, in which social, political, technological, economic and environmental conditions are organized. The plan can be expanded with the consideration of local, national and global forces (Hall. and Stephen, (2002)). At this stage, according to the mentioned materials, we examine and identify the key factors in the development of Qayen tourism industry. First, the required data were collected through a questionnaire and focus group method. The research population consisted of experts and authorities in urban area. At this stage, experts were asked to identify the most important factors in the development of Qayen's tourism industry. Then, by investigating the results of the data from the questionnaire, the effective factors of tourism of Qayen in 5 sections and 19 factors were set forth in Table 3. Then Mic Mac software has been used to extract the main influential factors for the development of Qayen tourism. The main thinking ruling this system is system thinking. Therefore, the main factors affecting the development of Qayen tourism are placed in rows and columns of $19 * 19$ matrix and then delivered to the experts 
for the impact of each factor on the other factor as a questionnaire. The experts ranked the effect of each factor in the row on each factor in the column based on the range from zero to 3 (zero / ineffectiveness, $1=$ impact, $2=$ medium impact, $3=$ high impact). In fact, with this valuation they determined that in the future how much each factor can affect other factors in development of tourism in Qayen. The data was first entered in the Mic Mac software. Then, according to the output results of this analysis, the degree of filling of the matrix was $89.55 \%$. It shows that the selected factors had a large and dispersed impact on each other in the system and was in the state of instability. Totally, 324 matrix relationships were evaluated, 146 relationships, $45.06 \%$, had crossover effects of 3, relationship of key factors were many and they have been very effective and impressible. 138 relationships i.e. $42.5 \%$ had crossover effects of 2 that mean they played a reinforcing role and the interface had a relatively moderate effect. 40 relationship equivalents to 12.3 percent had crossover effects of 1 , number one means that they had a weak relationship. 37 relationships that is a ratio of $11.4 \%$ had zero crossover effect, meaning that the factors did not affect each other. In general, from the table Under, it can be concluded that most relationships between variables are ranked 3 or very strong ( Table 1).

Table 1: Results from the impact of variables.

\begin{tabular}{lllllllll}
\hline $\begin{array}{l}\text { Matrix } \\
\text { dimensions }\end{array}$ & repetition & $\begin{array}{l}\text { No } \\
\text { effect } \\
\text { (0) }\end{array}$ & $\begin{array}{l}\text { effective } \\
(\mathbf{1})\end{array}$ & $\begin{array}{l}\text { Reinforcing } \\
\text { (2) }\end{array}$ & $\begin{array}{l}\text { empowering } \\
\text { (3) }\end{array}$ & count & $\begin{array}{l}\text { Filling } \\
\text { degree }\end{array}$ & sum \\
\hline $\mathbf{1 9}$ & 2 & 37 & 40 & 138 & 146 & 0 & 89.75 & 324 \\
\hline
\end{tabular}

On the other hand, the matrix is based on statistical indices with 2 times of data rotation of $100 \%$ desirability and optimization. As, the direct effect matrix and the direct potential effect matrix are $90 \%$ and $91 \%$ respectively, indicating high validity of the questionnaire and its responses ( Table 2 ).

Table 2: The degree of utility of the matrices.

\begin{tabular}{lll}
\hline Iteration & Influence & Dependence \\
\hline $\mathbf{1}$ & $91 \%$ & $90 \%$ \\
\hline $\mathbf{2}$ & $100 \%$ & $101 \%$ \\
\hline
\end{tabular}

Identification of key cultural effects in Qayen

In order to identify the most important indicators in the development of the tourism industry in Qayen, 19 indicators were analyzed through research and were set up by experts and executives in 5 sections and 19 key indexes with a $19 * 19$ matrix based on the analysis of crossover effects.

Table 3: Specifications of the primary factors influencing the development of tourism industry in Qayen city and their classification

\begin{tabular}{|c|c|}
\hline Social & $\begin{array}{l}\text { Urban village migration, Tourism offices, Database and statistics system in the field of } \\
\text { tourism, The role of civil society and the Youth NGOs }\end{array}$ \\
\hline Political & $\begin{array}{l}\text { Affiliation, Coordinated Tourism Management, The degree of authority assignment to } \\
\text { provincial and local levels }\end{array}$ \\
\hline Economic & $\begin{array}{l}\text { Increasing the private sector share of the tourism economy, The trend of the province } \\
\text { economy to diversify its tourism patterns, Urban and regional transportation networks, } \\
\text { Coordination of the private sector with government sectors, Development of hotel and } \\
\text { tourist infrastructure, Construction and strengthening of tourism infrastructure }\end{array}$ \\
\hline Environmental & Droughts and water crisis, Climate change \\
\hline Technological & $\begin{array}{l}\text { Development of the Internet of Things, Development of social networks. Development of } \\
\text { mobile applications, Specialized human power resource }\end{array}$ \\
\hline
\end{tabular}

\section{Analyzing direct effects of variables in each other}

In this method, each relationship of the variables with the powers of 5, 4, 3, 2, are calculated by software and the direct effects of the variables are measured accordingly. The distribution and transmittance of variables based on direct effects also indicate the system instability and redefine the five categories of key variables or influential, impressible, two-dimensional, regulatory, and independent variables. 


\section{Direct influence/dependence map}

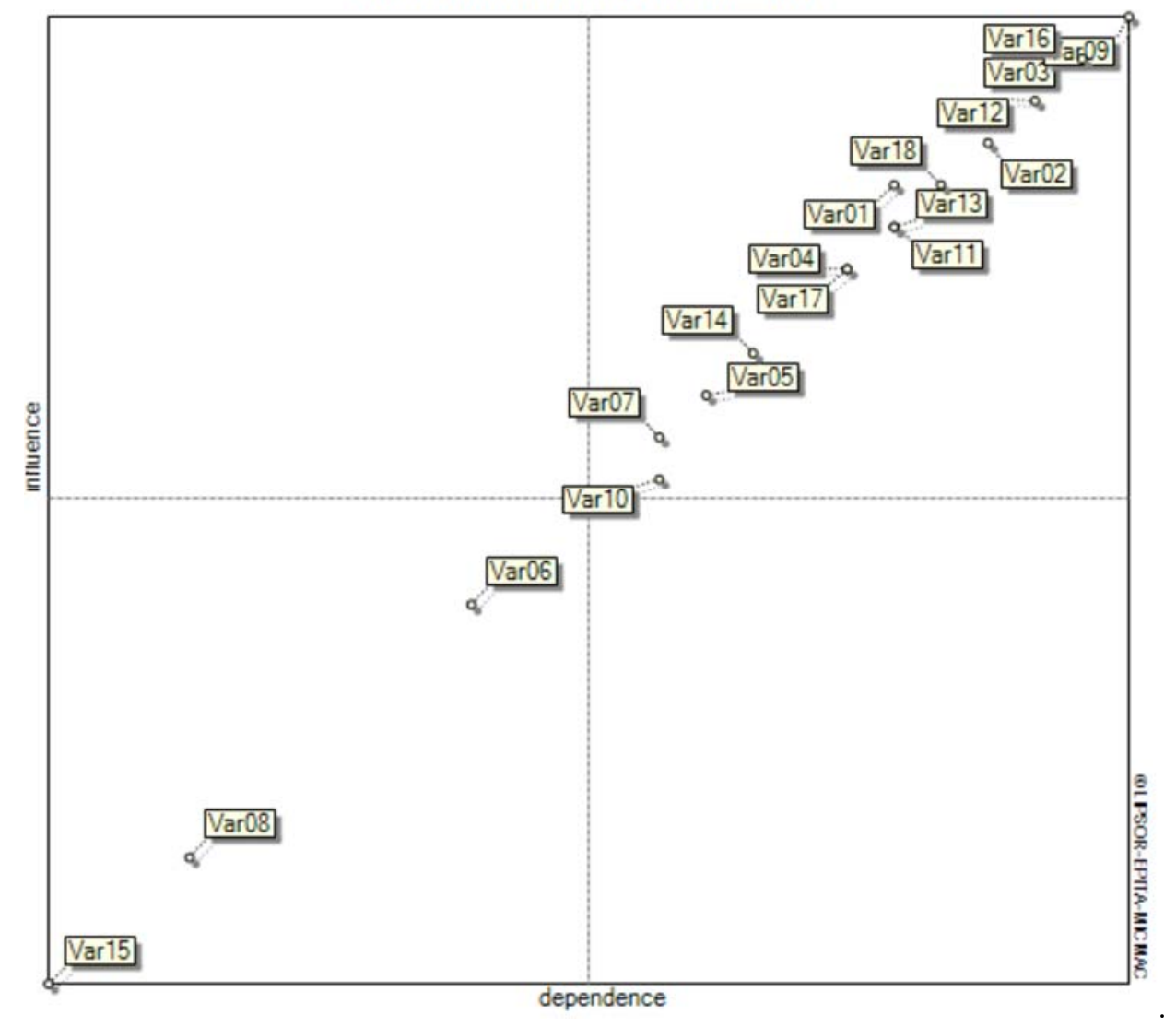

Figure 5. Transmittance map of indirect variables and their position in the impact-affecting axis.

\section{Risk variables}

These variables are about the northeast of the graph and have high capacity to become key actors of the system. These variables are as follow:

Urban rural migration, existence of tourism offices), share of private sector of tourism economy, database and statistics system in the field of tourism, role of civil and NGO institutions 'Diversification of the types of tourism, urban and regional transport companies, the coordination of the private sector with the public sector, state affiliation, the extent of authority assignment to provincial and local levels), coordinated management, specialist staff, development of hotel and Eco-tourism infrastructure, construction and strengthening of tourism infrastructure، Social Networks.

These risk variables can be related to the economic, social, and then political situation in Qayen.

\section{Independent variables}

These variables which are located in the southwest of map have low impact and impressibility, and due to system instability, most of the variables have the nature of the system output and should be called some kind of independent output variables.

Indirect independent variables include the Internet of objects (6), mobile apps (8), droughts and water crisis (15)

\section{Regulatory variables}

These variables are located near the center of gravity of the page and in the chart, we have 1 item for these variables.

The variables in this group include:

Urban and regional transport companies

According to Figure 5 and 6, direct relationships of Qayen development variables, one can say that from 19 variables of research, there are 11 variables with a very strong relationship among the 11 variables and the most impressible variable is the assignment of authority to provincial and local levels (13) (Figure 7 ). Which has the most impact compared to other variables and can also be identified as the target variable and ranked second in the development of hotel and Eco-tourism infrastructure (17), then the construction and improvement of tourism infrastructure and expert human resource variables are identified as the most influential variables. 
By reviewing and outputting the indirect effects Figure. 5), one can find out that six variables of

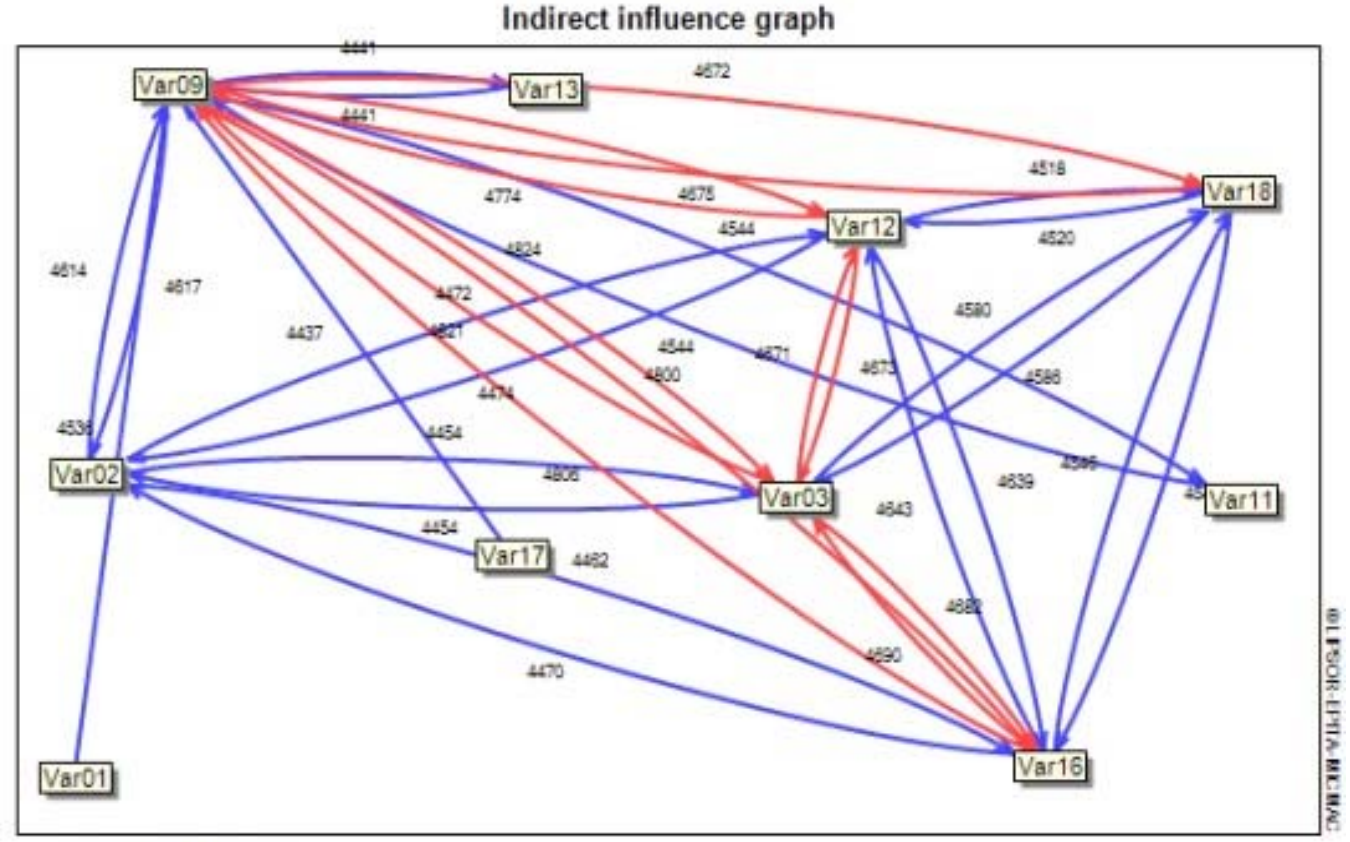

\footnotetext{
Weakest influences

- Weak influences

- Moderate influences

- Relatively strong influences

- Strongestinfluences
}

Figure 6. Indirect relationships between variables (very strong).

\section{Direçt influence graph}

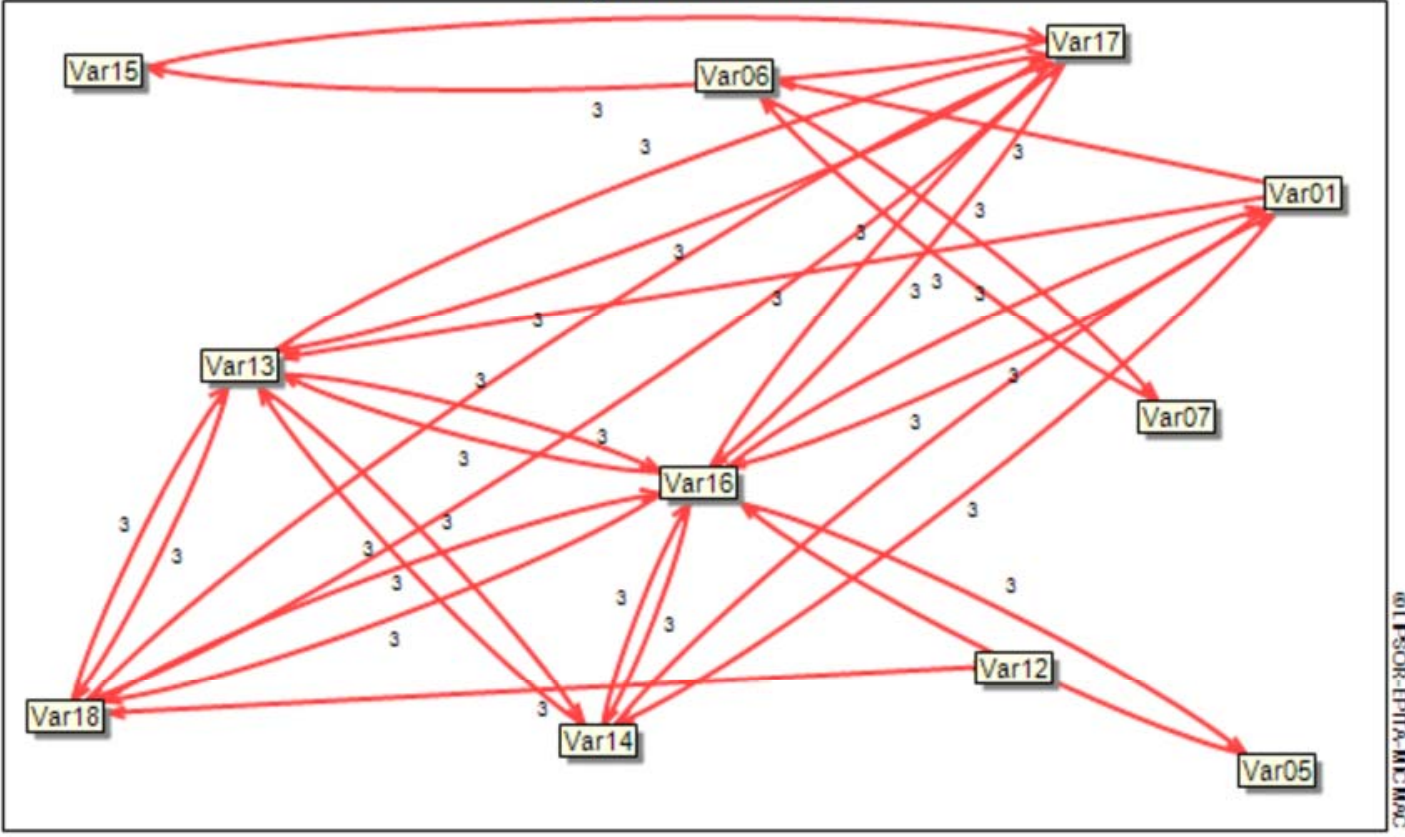

Weakest influences

Weak influences

Moderate influences

Relatively strong influences

- Strongest influences

Figure 7. The direct relationship between variables (very strong). 
Table 4: The rank of direct and indirect effects of the variables on each other for effective and impressible partitioning

\begin{tabular}{|c|c|c|c|c|c|c|c|c|}
\hline $\begin{array}{l}\text { Indirect } \\
\text { impressi } \\
\text { bility }\end{array}$ & Index & $\begin{array}{l}\text { Indirect } \\
\text { effectivity }\end{array}$ & Index & $\begin{array}{l}\text { Direct } \\
\text { impres } \\
\text { sibility }\end{array}$ & Index & $\begin{array}{l}\text { Direct } \\
\text { impress } \\
\text { ibility }\end{array}$ & Index & Rank \\
\hline 628 & $\begin{array}{ll}\text { tendency } & \text { of } \\
\text { province } & \text { to } \\
\text { diversify } 9 & \end{array}$ & & $\begin{array}{ll}\text { tendency } & \text { of } \\
\text { province } & \text { to } \\
\text { diversify } 9 & \end{array}$ & & $\begin{array}{l}\text { tendency of } \\
\text { province to } \\
\text { diversify } 9\end{array}$ & & $\begin{array}{l}\text { tendency of } \\
\text { province to } \\
\text { diversify } 9\end{array}$ & 1 \\
\hline 613 & $\begin{array}{l}\text { The share of private } \\
\text { sector from tourism } \\
\text { economy } \\
3\end{array}$ & & $\begin{array}{l}\text { The share of private } \\
\text { sector from tourism } \\
\text { economy } \\
3\end{array}$ & & $\begin{array}{l}\text { The share of } \\
\text { private sector } \\
\text { from tourism } \\
\text { economy } \\
3\end{array}$ & & $\begin{array}{l}\text { The share of } \\
\text { private } \\
\text { sector from } \\
\text { tourism } \\
\text { economy } \\
3\end{array}$ & 2 \\
\hline 608 & $\begin{array}{l}\text { Expert human } \\
\text { resource } 16\end{array}$ & & $\begin{array}{l}\text { Expert human } \\
\text { resource } 16\end{array}$ & & $\begin{array}{l}\text { Expert } \\
\text { human } \\
\text { resource } 16\end{array}$ & & $\begin{array}{l}\text { Expert } \\
\text { human } \\
\text { resource } 16\end{array}$ & 3 \\
\hline 607 & $\begin{array}{l}\text { Governmental } \\
\text { Entrepreneurship } \\
12\end{array}$ & & $\begin{array}{l}\text { Governmental } \\
\text { Entrepreneurship } \\
12\end{array}$ & & $\begin{array}{l}\text { Governmenta } \\
1 \\
\text { Entrepreneur } \\
\text { ship } \\
12\end{array}$ & & $\begin{array}{l}\text { Government } \\
\text { al } \\
\text { Entrepreneu } \\
\text { rship } \\
12\end{array}$ & 4 \\
\hline 593 & $\begin{array}{lr}\begin{array}{l}\text { Construction } \\
\text { strengthening }\end{array} & \text { and } \\
\text { tourism } & \\
\text { infrastructure } & \\
18 & \end{array}$ & & $\begin{array}{l}\text { Construction and } \\
\text { strengthening of } \\
\text { tourism } \\
\text { infrastructure } 18\end{array}$ & & $\begin{array}{l}\text { Existence of } \\
\text { tourism } \\
\text { offices } \\
2\end{array}$ & & $\begin{array}{l}\text { Existence of } \\
\text { tourism } \\
\text { offices } \\
2\end{array}$ & 5 \\
\hline 586 & $\begin{array}{l}\text { Existence } \\
\text { tourism offices } \\
2\end{array}$ & & $\begin{array}{l}\text { Existence } \\
\text { tourism offices } \\
2\end{array}$ & & $\begin{array}{l}\text { Construction } \\
\text { and } \\
\text { strengthening } \\
\text { of tourism } \\
\text { infrastructure } \\
18\end{array}$ & & $\begin{array}{l}\text { Constructio } \\
\mathrm{n} \quad \text { and } \\
\text { strengthenin } \\
\mathrm{g} \text { of tourism } \\
\text { infrastructur } \\
\mathrm{e} \\
18\end{array}$ & 6 \\
\hline 577 & $\begin{array}{l}\text { Coordination of the } \\
\text { private sector with } \\
\text { government sectors } \\
11\end{array}$ & & $\begin{array}{l}\text { Coordination of the } \\
\text { private sector with } \\
\text { government sectors } \\
11\end{array}$ & & $\begin{array}{l}\text { Urban rural } \\
\text { immigration } \\
1\end{array}$ & & $\begin{array}{l}\text { Urban rural } \\
\text { immigration } \\
1\end{array}$ & 7 \\
\hline 564 & $\begin{array}{l}\text { assignment of } \\
\text { authority to } \\
\text { provincial and local } \\
\text { levels 13 }\end{array}$ & & $\begin{array}{l}\text { Urban } \\
\text { immigration } 1\end{array}$ & & $\begin{array}{l}\text { Coordination } \\
\text { of the private } \\
\text { sector with } \\
\text { government } \\
\text { sectors } \\
11\end{array}$ & & $\begin{array}{l}\text { Coordinatio } \\
\mathrm{n} \text { of the } \\
\text { private } \\
\text { sector with } \\
\text { government } \\
\text { sectors } \\
11\end{array}$ & 8 \\
\hline 562 & $\begin{array}{l}\text { Development of } \\
\text { hotel and Eco- } \\
\text { tourism } \\
\text { infrastructure } 17\end{array}$ & & $\begin{array}{l}\text { assignment of } \\
\text { authority } \\
\text { provincial and local } \\
\text { levels 13 }\end{array}$ & & $\begin{array}{l}\text { Variable } \\
4\end{array}$ & & $\begin{array}{l}\text { Database } \\
\text { and } \\
\text { statistics } \\
\text { system in } \\
\text { the field of } \\
\text { tourism } \\
4\end{array}$ & 9 \\
\hline 562 & $\begin{array}{l}\text { Urban } \\
\text { immigration } 1\end{array}$ & & $\begin{array}{l}\begin{array}{l}\text { Development of } \\
\text { hotel and Eco- } \\
\text { tourism } \\
\text { infrastructure } 17\end{array}\end{array}$ & & $\begin{array}{l}\text { assignment } \\
\text { of authority } \\
\text { to provincial } \\
\text { and local } \\
\text { levels 13 }\end{array}$ & & $\begin{array}{l}\text { assignment } \\
\text { of authority } \\
\text { to } \\
\text { provincial } \\
\text { and local } \\
\text { levels } 13\end{array}$ & 10 \\
\hline
\end{tabular}




\begin{tabular}{|c|c|c|c|c|c|}
\hline 527 & $\begin{array}{l}\text { Database and } \\
\text { statistics system in } \\
\text { the field of tourism } \\
4\end{array}$ & $\begin{array}{l}\text { Database and } \\
\text { statistics system in } \\
\text { the field of tourism }\end{array}$ & $\begin{array}{l}\text { Development } \\
\text { of hotel and } \\
\text { Eco-tourism } \\
\text { infrastructure } \\
17\end{array}$ & $\begin{array}{l}\text { Developme } \\
\text { nt of hotel } \\
\text { and Eco- } \\
\text { tourism } \\
\text { infrastructur } \\
\text { e } 17\end{array}$ & 11 \\
\hline 500 & $\begin{array}{l}\text { Coordinated } \\
\text { management } \\
14\end{array}$ & $\begin{array}{l}\text { Coordinated } \\
\text { management } \\
14\end{array}$ & $\begin{array}{l}\text { The Role of } \\
\text { Civil and } \\
\text { NGO } \\
\text { Institutions } 5\end{array}$ & $\begin{array}{l}\text { The Role of } \\
\text { Civil and } \\
\text { NGO } \\
\text { Institutions } \\
5\end{array}$ & 12 \\
\hline 497 & $\begin{array}{l}\text { The Role of Civil } \\
\text { and } \\
\text { Institutions } 5\end{array}$ & $\begin{array}{l}\text { The Role of Civil } \\
\text { and } \\
\text { Institutions } 5\end{array}$ & $\begin{array}{l}\text { Coordinated } \\
\text { management } \\
14\end{array}$ & $\begin{array}{l}\text { Coordinated } \\
\text { managemen } \\
\text { t } 14\end{array}$ & 13 \\
\hline 451 & Social networks 7 & Social networks 7 & $\begin{array}{l}\text { Social } \\
\text { networks } 7\end{array}$ & $\begin{array}{l}\text { Urban and } \\
\text { regional } \\
\text { transportati } \\
\text { on } \\
\text { companies } \\
10\end{array}$ & 15 \\
\hline 383 & Internet of objects 6 & Internet of objects 6 & $\begin{array}{l}\text { Internet } \\
\text { objects } 6\end{array}$ of & $\begin{array}{l}\text { Internet of } \\
\text { objects } 6\end{array}$ & 16 \\
\hline 375 & Climatic changes 19 & Climatic changes 19 & $\begin{array}{l}\text { Climatic } \\
\text { changes } 19\end{array}$ & $\begin{array}{l}\text { Climatic } \\
\text { changes } 19\end{array}$ & 17 \\
\hline
\end{tabular}

Table 5: Effective Factors (Amazing Drivers)

\begin{tabular}{|c|c|c|}
\hline row & Key factors (direct impacts) & Key factors (indirect impacts) \\
\hline 1 & The tendency of province to diversify tourism & $\begin{array}{l}\text { The tendency of province to diversify } \\
\text { tourism }\end{array}$ \\
\hline 2 & Share of private sector of tourism economy & $\begin{array}{l}\text { Share of private sector of tourism } \\
\text { economy }\end{array}$ \\
\hline 3 & Governmental Entrepreneurship & Expert human resource \\
\hline 4 & Expert human resource & Governmental Entrepreneurship \\
\hline 5 & Existence of tourism offices & $\begin{array}{l}\text { Construction and strengthening of } \\
\text { tourism infrastructure }\end{array}$ \\
\hline 6 & Construction and strengthening of tourism infrastructure & Existence of tourism offices \\
\hline 7 & Urban rural immigration & $\begin{array}{l}\text { Coordination of the private sector with } \\
\text { government sectors }\end{array}$ \\
\hline 8 & Coordination of the private sector with government sectors & Urban rural immigration \\
\hline 9 & Database and statistics system in the field of tourism & $\begin{array}{l}\text { assignment of authority to provincial } \\
\text { and local levels }\end{array}$ \\
\hline
\end{tabular}

According to Table 4, Among the 19 factors examined, the factors and variables in the direct impact method and in the indirect impacts method are derived from the following table ( Table 5 ): 


\section{The final selection of the main factors affecting the development of tourism in Qayen}

Tourism as a remunerative industry has attracted many countries and cities. One of the major tourist destinations of Khorasan is Qayen City which welcomes a number of tourists by its annual historical, cultural and natural capacities. At this time, two organizations are responsible for tourist affairs in Qayen, including organizations such as Cultural Heritage, Handicrafts and Tourism Organization and Municipality of Qayen. In this study, among the 19 factors studied, the information obtained from the analysis of the extent to which the variables influence each other and the direct and indirect effects diagrams below, confirm that the stability of the tourism industry system in Qayen is in a high level. So that the distribution of key variables is more closely located in the main axis of the Northeast, and studied variables are more effective. One of the most important reasons of positive and historical image of Qayen is that this city has a strong background in the areas mentioned. The tourism attractions of Qayen are categorized into three categories: historical, spiritual and natural. The national works of Qayen are divided into three groups of natural phenomena (17), historical phenomena (43) and spiritual phenomena (2).

Qayen has 2 museums, including the Museum of Water and the Museum of Fame and Anthropology. Among the important handicrafts of this city is carpet, basket weaving, hand weaving, etc. Qayen has no hotels in terms of tourism facilities. Approximately 2.1 hectares of urban land (8.29\%) is allocated to the use of tourism and per capita of 8.5 square meters. The extent of this use for the review of general plan is about 2.0 hectares and per capita 8.52 Square meters are planned and to reach this level, about 9.3 hectares of land will be needed with tourist use. The per capita approved by the Supreme Council for this use is 8.2 square meters. Therefore, the existing situation is in desirable condition compared to approve per capita, so there is not a shortage in this area and it should be planned to improve quality. The human resources of Qayen's Cultural Heritage, Handicrafts and Tourism Office are totally 5 people. Therefore, there is no logical relation between the realization of goals and the human resource structure of specialist human resource of cultural heritage, handicrafts and tourism of the city, however Qayen has a very high potential for development of tourism both in historical and in natural attractions.

According to experts, 5 factors have been selected as the main factors affecting the development of tourism in Qayen. These factors include the tendency of provincial economy to diversify the types of tourism, the share of private sector from tourism economy, governmental entrepreneurship, specialized human resources, the existence of tourism offices, the construction and strengthening of tourism infrastructure.

At the same time, with key factors such as governmental entrepreneurship, the tendency of provincial economy to diversify the types of tourism, the share of private sector from the tourism economy, the presence of specialist forces, it can be admitted that in accordance with Article 44 of the Constitution, government has the authority of many economic activities. This suggests that the constitution does not allow the entry, activity, and competition of the private sector with the public sector. Since government possesses authority of many large industries and organizations, the private sector is weakened and does not have the necessary incentive to invest.

In both internal and external dimensions, this has caused a downturn on the tourism industry in Iran. The lack of willingness of the private sector to invest in this sector due to lack of provision and assurance of government ownership and support, as well as the reluctance of multinational companies to participate in the Iranian economy due to the legal prohibition and limiting the activities of these companies, according to political imperatives, economic, and cultural factors are some of the factors that prevent private investment in relation to the growth and development of the tourism industry. At the same time, it should not be forgotten that the adoption and notification of the general policies of Article 44 of the Constitution since 2005 has created the capacity and legal openings for the presence of the private sector in the country's tourism sector. On the other hand, the presence of specialist human resources can have an effective role in tourism development due to management potential in the field of planning, collection of tourism information database, education, and development of tourism culture.

\section{Conclusion}

Today, the flow of tourism in the world has developed widely, and many countries in this sector have been able to improve their status to a considerable extent and to cover a number of issues, such as unemployment, falling per capita income, and the lack of foreign exchange earnings. Due to the dramatic effects that tourism activities have on the economy of the receiving regions of tourists, much attention is paid to this field of activities. Meanwhile, the most important places that tourists visited and stayed are the places that made up the most attractive spaces from a long time ago. Today, managers and planners are looking to attract more and more tourists, in addition to building a variety of residential and shopping centers, not only to rebuild historical buildings and cultural centers, but also to create and construct modern textiles. It is worth pointing out that by attracting more tourists into urban environments, the problem of municipal budget deficits will be resolved to a large extent and municipalities will be able to act better to their legitimate duties. The present study shows that in many researches on tourism, such as: Yeoman et al., in an article titled as "Scottish Tourism: Scenarios and Landscapes", published in 2005, create four scenarios of the future for Scotland. A "dynamic" scenario creates 10 billion pounds of tourism and makes the tourism industry the number one industry in Scotland. The "Weekend Getaway" scenario sees the 
tourist based on consumerism and entertainment. The value of tourism in this scenario is 7.6 billion pounds. "The destination of yesterday" is tourism based on the past, and the tourism industry will satisfy itself. The noncompetitive industry means that it grows only $1 \%$ a year and has a value of 5.1billion pounds. Finally, "Scotland exclusive" means that the Scottish economy by reducing the price of the soul out of the economy has failed but the favorable exchange rate means that lucrative tourists run to certain resorts. Tourism in this scenario is an industry of 2.6 billion pounds. These four scenarios follow different paths and are affected by different conditions. But in all cases, there is a tourist. Scotland's opportunity is to maximize its potential to turn the tourism industry into Scotland's first and lasting industry.

and Atariyan et al. (2015), the findings based on investing in the general tourism plan, budget, macroeconomic policies, media, incentive policies, rules and regulations of the tourism, technical knowledge;. Finally, to development and improvement of the tourism industry of Qayen, in addition to the restrictions, suggestions are given as follows.

\section{Limitations and suggestions:}

Based on the results of questionnaires and interviews with relevant experts on the competitive advantage of Qayen in the field of tourism, Given the capacity of this city in the horizon of 1404 the following limitations have been identified and suggestions have been made::

- Inadequacy of residential and welfare services

- Lack of essential infrastructure for entering and retaining tourists

- Very weak informing about the historical and natural attractions and tourist attractions to attract tourists

- The lack of precise statistics on the number of tourists, the time of residence etc. in Qayen

- Lack of efficient, expert and experienced human resource in Qayen

- Lack of fund to restore and strengthen the historical attractions of the city

- The lack of urban tourism elements in the city

- Lack of planning and local investment in the tourism industry

- Lack of information base in spite of existing historical and natural attractions

- Unauthorized construction on the territory of historical monuments

\section{Suggestions}

- The development of Qayen comprehensive tourism plan; the lack of a tourism road map for the city is considered a major weakness in the development of the tourism industry in Qayen. With the development and implementation of the comprehensive tourism plan of the city, in the future, we will see a change in the tourism and employment in the city.

- Introducing new tourist destinations; tourists are seeking for new destinations in their leisure time in Qayen, and introducing new destinations to domestic tourists could boost these destinations and gradually make them among foreign tourism choices. An item that can introduce the city to the world and consequently distribute the incomes of the tourism industry to the income of all the people of the city.

- The use of expert human resources as well as the cooperation and participation of academics, experts, researchers, and students of the province and the city in various fields of development of the tourism industry of Qayen

- Organizing educational classes to promote the culture of tourism in the indigenous community based on domestic and foreign tourism

- Investing through the private sector

- Increasing welfare services and infrastructure; in strategies for tourism development, there needs to be a balanced growth, which means that the necessary infrastructure should be provided to the same extent as to increase the tourists' statistics and the tourism prosperity of the city.

- Investing in transport and strengthening regional transport

- Attention to the capacity and tolerance threshold of $t$ tourist areas in the city to prevent the destruction of nature

- More attention to tourism in the field of rural activities around Qayen based on the customs of the villagers such as livestock, agriculture, etc.

Data availability

We will share all the details if needed. 


\section{References}

[1] Hall, M., and Stephen, J. (2002). The Geography of Tourism and Recreation: Environment, Place, and Space, Rutledge Publisher, edition 2nd, 200 .

[2] Kazemi, M. (2010). Tourism Management, Khome Publications, Second Edition.

[3] Khatai, M., Mousavi, F., Mousavi, M.R., and Mousavi, A. (2008). Measuring the Performance of Tehran Hotels Using Analytical Data Envelopment Method. Journal of Economic Research, 8(2), 2-2.

[4] Khazaei, S. (2005). Principles and Concepts Monitoring, Defense Industry Training and Research Institute, Defense Science and Technology Future Research Center.

[5] Mirkatouli, J., and Mossadegh, R. (2011). Investigation of Rural Tourism Status and Its Role in Craftsmanship (Case Study: South Esterabad District), Journal of Urban and Regional Studies, 7, 137-154.

[6] Qaderi, R., Hadiani, Z., Mohammadi, K., and Abu Bakri, T. (2011). Regional Tourism Planning Strategies Using Swat Technique (Case Study: Piranshahr City), Regional Planning Quarterly, First Year, (3), 27-43.

[7] Rahnama, M.R., and Maroufi, A. (2015). Scenography in Urban and Regional Studies (Concepts, Methods and Experiences). Published by the Research Center of the Islamic Council of Mashhad.

[8] Taghdisi, A., Inheritant, H.R., Ahmadian, M., and Askari, Hamid. (2015). Identification and Analysis of Factors Affecting Tourism Development in Rural Areas (Case Study: Rural Areas of Jiroft County Journal of Rural Research and Planning, 4(1), 1-14

[9] Yeoman, I., and Lederer, P. (2005). Scottish tourism: Scenarios and vision. Journal of Vacation Marketing, $11,17$.

[10] Zali, N. (2012). Strategic Forecasting and Regional Policy Making with a Scenario Writing Approach, Journal of Political Science, Strategic Studies, 4(54), 33-54.

[11] Zali, R. (2002). Regional Development Forecasting with Baseline Scenario Planning Approach (Case Study: West Azerbaijan Province). Tabriz University. 